\title{
Morphometric Differences in Testicular Tissue of Tadarida brasiliensis Bats from the Urban Area of Mexico City During Summer, Autumn, and Winter
}

\author{
Diferencias Morfométricas en Parenquima Testicular de Murcielagos Tadarida brasiliensis \\ del Área Urbana de la Ciudad de México en Verano, Otoño e Invierno
}

\author{
Juan J. Pérez-Rivero*; Emilio Rendon-Franco*; Mario Pérez-Martínez**; \\ Alejandro Ávalos-Rodríguez \& Rafael Ávila-Flores***
}

PÉREZ-RIVERO, J.; RENDON-FRANCO, E.; PÉREZ-MARTÍNEZ, M.; ÁVALOS-RODRIGUEZ, A. \& AVILA-FLORES, R. Morphometric differences in testicular tissue of Tadarida brasiliensis bats from the urban area of Mexico City during summer, autumn, and winter. Int. J. Morphol., 31(3):932-936, 2013.

SUMMARY: Most of the neotropical bats reproduce in a seasonal fashion. The purpose of this study was to assess changes in testicular tissue by morphometry, in Tadarida brasiliensis bat, in a south urban zone of Mexico City during summer, autumn, and winter. Three sample collections (February, June, and September) from T. brasiliensis were carried out ( $\mathrm{n}=6)$. Testicle fragments were obtained for histological studies. Diameter of the seminiferous tubules and interstitial space were measured, cellular populations were identified and counted. June samples showed smaller diameter of seminiferous tubules and larger interstitial space between tubules; also there were less number of germinal epithelium cells and spermatids were absent. Tissues from September and February showed a significant increase $(p \leq 0.05)$ in tubule diameter, germinal epithelium thickness, and number of germinal epithelium cells when compared to June samples. Only February samples showed presence of spermatids. Our results suggest the existence of seasonal variations in the reproductive activity of $T$. brasiliensis, under conditions in which the study was conducted.

KEY WORDS: Tadarida brasiliensis; Morphometry; Testicle; Seasonal changes.

\section{INTRODUCTION}

Studies on the reproductive biology of bats state that the diversity of reproductive patterns is associated to the magnitude of climatic fluctuations and to the variability in food availability throughout the year (Racey \& Entwistle, 2000). Furthermore, geographic variation has been detected in the reproductive pattern of a same species, particularly in species that are widely distributed (Happold \& Happold, 1989).

Tadarida brasiliensis is a species distributed throughout America, their reproduction is seasonal and females are monoestrus, however, their reproductive activity may vary depending on the latitude inhabited (Krutzsch et al., 2002). For example, while in Florida (USA) mature sperm can be observed in the epididymis between February and March, in Cordoba (Argentina) spermatozoa are present from July to October (Wilkins 1989).
Due to their plasticity, T. brasiliensis is one of the most tolerant species to habitat transformation (Ávila-Flores \& Fenton, 2005). Although it is known that various anthropogenic factors can alter the reproductive activity of bats (Stebbings, 1988), little is known on the performance of $T$. brasiliensis in highly disturbed environments. It has been stated that the reproductive activity of male $T$. brasiliensis bats starts when they reach sexual maturity in their second year of life, initiating spermatogenesis in the months of February and March (Wilkins). In addition, what is interesting is to analyze the reproductive activity in species inhabiting highly polluted areas. The capacity of adapting to these environments is what allows the characterization of a particular species as having high plasticity (Bernanke \& Köhler, 2009).

Testis morphometry has been very useful in several

\footnotetext{
" Departamento de Producción Agrícola y Animal, Universidad Autónoma Metropolitana, Unidad Xochimilco, Ciudad de México, México.

*** Departamento de Morfología, Facultad de Medicina Veterinaria y Zootecnia, Universidad Nacional Autónoma de México, Ciudad de México, México. ****Instituto de Ecología, Universidad Nacional Autónoma de México, Circuito Exterior S/N, Ciudad de México, México.
} 
studies in other species for it allows identifying changes in the number of different types of cells of the seminiferous epithelium and in the interstitial compartment. This information is necessary to understand the testis function under different environmental conditions (Schön et al., 2004; Almeida et al., 2006).

The purpose of this study was to describe the morphometry of the testicular parenchyma of T. brasiliensis in individuals that use an urban refuge in Mexico City during the months of February, June, and September, by evaluating the morphometric characteristics of testis.

\section{MATERIAL AND METHOD}

Samples were collected from a T. brasiliensis colony that seeks refuge among the buildings in a housing complex in the South of Mexico City (19¹7'47' N, 9906'13" W, 2241 masl). We used nets to capture 6 male T. brasiliensis in the months of June and September of 2010 and February 2011 ( $\mathrm{N}=2$ individuals/sampling). We decided to use a small sample size to not adversely affect the small colony of bats existing in the studied habitat.

Individuals were identified using the field guide of Medellin et al. (2008). Each individual was handled and sacrificed according to the recommendations of the American Society of Mammalogists (Gannon \& Sikes, 2007).

Immediately after sacrificing with intrathoracic injection of sodium pentobarbital, testicles were obtained from bats and each was cut longitudinally in half and fixed in Bouin solution for 8 hours; after fixation, they were kept in $70 \%$ ethanol until processed with the technique of embedding in paraffin. Tissues were cut on a microtome, 6- $\mu \mathrm{m}$ thickness, and were stained with hematoxylin and eosin and Methyl Green Pyronin (Estrada et al., 1982).

Morphometric analysis was performed independently by two observers who measured the diameter of the seminiferous tubules (taking into account the middle part of the longitudinal plane of each tubule) and the space between the seminiferous tubules, using an optical microscope under a 40X objective lens. Cell counting and measurements were carried out on nine randomly selected microscope fields in 3 slices of testicular tissue from each animal. Images were obtained from microscopic fields, cell types on the basis of nuclear morphology and cell position within the seminiferous epithelium were identified as spermatogonia, spermatocytes, spermatids, Sustentacular and Intestitial cells (Beguelini et al., 2009), to perform the counting. For measurements we used the LSM5 Image Analyzer (Zeiss® Alemania). MannWhitney U test was used to compare cell counts and measurements among samples in the Paleontological Studies (PAST) program, ver. 1.81 (Hammer et al., 2001).

\section{RESULTS}

June samples showed seminiferous tubules with lesser thickness in the germination epithelium, larger interstitial space between tubules, less number of germination epithelium cells, and absence of spermatids, when compared to September and February samples $(\mathrm{p} \leq 0,05)$. In contrast, the samples from September and February showed significant increase in the diameter of the seminiferous tubules, thickness of germinal epithelium, and the number of cells in the germinal epithelium when compared to samples from June $(\mathrm{p} \leq 0.05)$. It is noteworthy that spermatids were only observed in samples obtained in February (Table I and Figure 1).

Table I. Mean morphometric and cell counting values of seminiferous tubules of Tadarida brasiliensis bats in three months of the year.

\begin{tabular}{lccc}
\hline Parameter & $\begin{array}{c}\text { June } \\
\text { (Summer) } \\
\text { Mean } \pm \text { SD }\end{array}$ & $\begin{array}{c}\text { September } \\
\text { (Autumn) } \\
\text { Mean } \pm \text { SD }\end{array}$ & $\begin{array}{c}\text { February } \\
\text { (Winter) } \\
\text { Mean } \pm \text { SD }\end{array}$ \\
\hline Tubular Diameter & $70 \pm 9 \mu \mathrm{m}^{\mathrm{a}}$ & $126 \pm 25 \mu \mathrm{m}^{\mathrm{b}}$ & $129 \pm 17 \mu \mathrm{m}^{\mathrm{b}}$ \\
Space between seminiferous tubules & $36 \pm 6 \mu \mathrm{m}^{\mathrm{a}}$ & $20 \pm 12 \mu \mathrm{m}^{\mathrm{b}}$ & $7 \pm 1 \mu \mathrm{m}^{\mathrm{c}}$ \\
Germinal epithelium thickness & $9 \pm 1 \mu \mathrm{m}^{\mathrm{a}}$ & $23 \pm 3 \mu \mathrm{m}^{\mathrm{b}}$ & $33 \pm 5 \mu \mathrm{m}^{\mathrm{c}}$ \\
Spermatogonia & $5 \pm 1 \mathrm{a}$ & $18 \pm 7 \mathrm{~b}$ & $15 \pm 1 \mathrm{c}$ \\
Sustentacular cells & $3 \pm 1 \mathrm{a}$ & $6 \pm 1 \mathrm{~b}$ & $7 \pm 2 \mathrm{~b}$ \\
Spermatocytes & $9 \pm 2 \mathrm{a}$ & $25 \pm 9 \mathrm{~b}$ & $68 \pm 8 \mathrm{c}$ \\
Instertitial cells & $10 \pm 1 \mathrm{a}$ & $11 \pm 3 \mathrm{~b}$ & $11 \pm 3 \mathrm{~b}$ \\
Spermatids & 0 & 0 & $19 \pm 5 \mathrm{a}$ \\
\hline
\end{tabular}

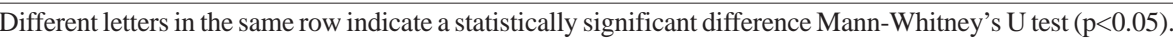




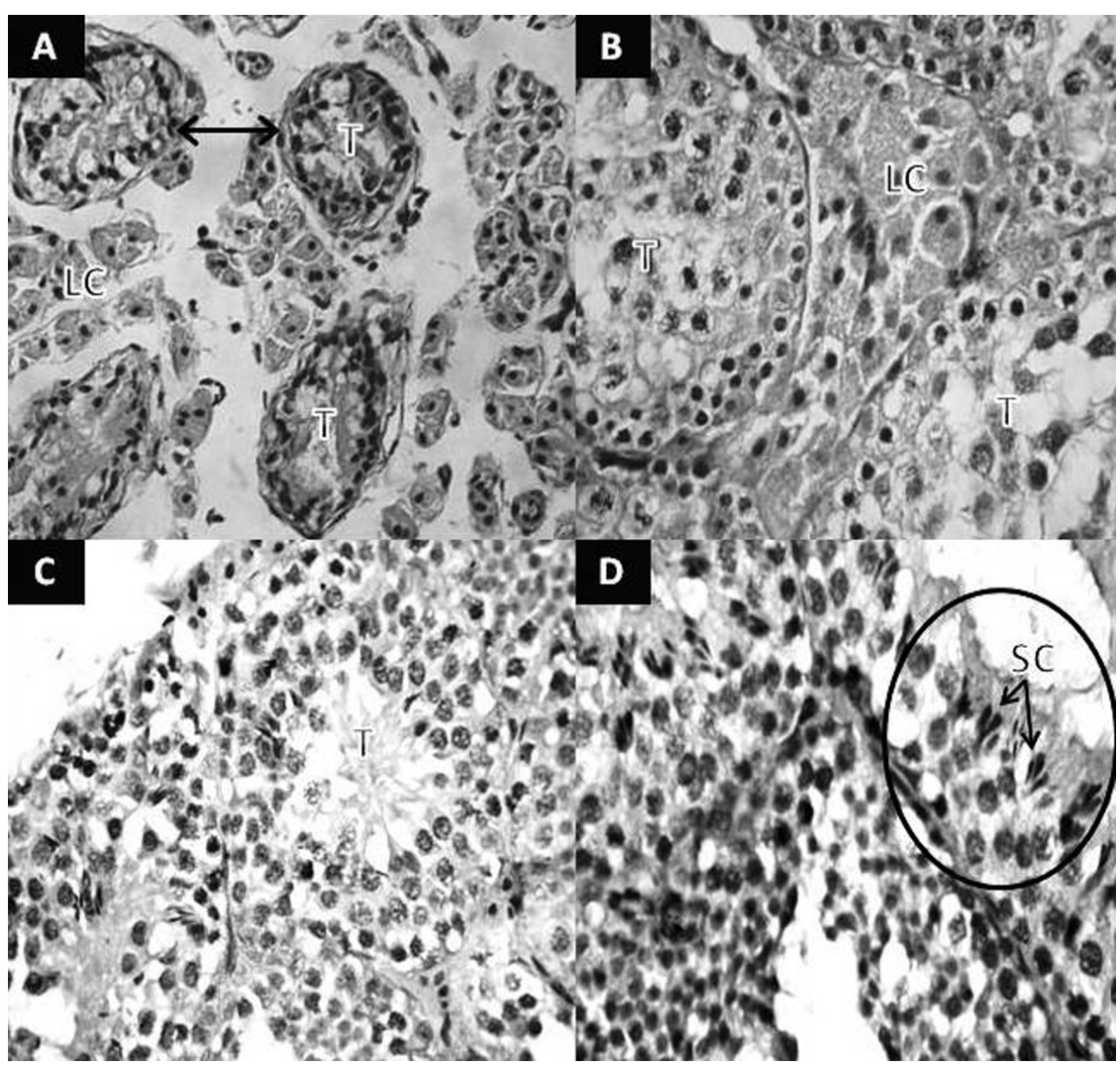

Figure 1. (A) Microphotograph of seminiferous tubules (T) corresponding to the month of June showing increased intertubular space (double arrow) (Hematoxilin and Eosine stain, $\mathrm{x} 10$ ). Leydig's cells (LC) can be seen in the interstitial space. (B) Microphotograph showing increased cell number in the seminiferous epithelium and a decrease in the interstitial space in samples from September (Methyl Green Pyronin stain, x20). (C) Seminiferous tubules with high number of cell in the germinal epithelium in samples from February (Hematoxilin and Eosine stain, x20). (D) Seminiferous tubules from samples from February in which spermatids (SC) can be seen (arrows) (Methyl Green Pyronin stain, $\mathrm{x} 40$ ).

\section{DISCUSSION}

Morphometric studies on chiropteran's seminiferous tubules are scarce. Our study describes for the first time the morphometric characteristics of the testicular parenchyma of T. brasiliensis that inhabit an urban environment in Mexico City in three periods of the year.

Krutzsch et al., reported for T. brasiliensis caught in southern United States, histological annual changes in testicles. During summer, primary spermatocytes began dividing, and seminiferous tubules were small; in autumn, seminiferous tubules began to enlarge; from November to December, primary and secondary spermatocytes were more abundant and Sertoli cells with spermatids were prominent; by winter, sperm was more abundant in seminiferous tubules, and a few sperm was present in the epididymis. These qualitative results agree with our quantitative findings and together, these data indicate that the greatest reproductive activity in T. brasiliensis males can be seen at the end of winter.
For most mammals, it is known that seasonal changes in the reproductive activity could be related with factors such as food availability and relative humidity and temperature (Fietz et al., 2005). In this regards, there are studies that indicate that the reproductive patterns of bats are associated to the magnitude of climatic fluctuations and to the variability in food availability throughout the year (Romano et al., 1999; Racey \& Entwistle).

Studies carried out in the southern hemisphere confirm that the reproductive activity of male $T$. brasiliensis reaches its highest level during winter, although the temporal pattern is inverted due to the differences in latitude. In a study performed in northern Argentina, authors observed an increase in interstitial space and presence of Sustentacular cells and some spermatogonia in the testicles of animals captured between the months of October and March, which corresponds to spring and summer in that hemisphere.

Our results contribute to the understanding of the complex structuring of migratory T. brasiliensis populations in the northern hemisphere. The available information suggests that breeding of migratory populations occurs in transitory refuges in northern Mexico during February to March, just at the time when females return to summer refuges (Russell et al., 2005).

Together, our results indicate the existence of variations in the reproductive activity of $T$. brasiliensis throughout the year. These results suggest that there is a significant reduction in sexual activity during summer. Understanding the feeding behavior and reproductive-cycle patterns of $T$. brasiliensis in urban areas allows the identification of 
periods and areas that are critical for their conservation. These studies are essential for the understanding of the role of the $\mathrm{T}$. brasilensis colony in the urban ecosystem from south of Mexico City.
ACKNOWLEDGEMENTS.Thank our students Christian Cerecedo Galindo and Laura Gonzalez Rodríguez for their contribution in field and laboratory work.

PÉREZ-RIVERO, J.; RENDON-FRANCO, E.; PÉREZ-MARTÍNEZ, M.; ÁVALOS-RODRIGUEZ, A. \& AVILA-FLORES, R. Diferencias morfometricas en parenquima testicular de murcielagos Tadarida brasiliensis del area urbana de la Ciudad de México en verano, otoño e invierno. Int. J. Morphol., 31(3):932-936, 2013.

RESUMEN: La mayoría de los murciélagos neotropicales se reproducen de manera estacional. El objetivo de este estudio fue determinar los cambios morfométricos en el parénquima testicular del murciélago Tadarida brasiliensis que habita en un área urbana del sur de la Ciudad de México durante las estaciones de verano, otoño e invierno. Se obtuvieron fragmentos de tejido testicular para su estudio histológico. Se midió el diámetro de los túbulos seminíferos y el espacio interstisial y se identificaron y contaron distintos tipos celulares. En las muestras de junio se encontró un menor diámetro de los túbulos seminíferos y un mayor espacio intersticial entre los túbulos; también hubo un menor número de células del epitelio germinal y no hubo presencia de espermátides. En las muestras de tejido obtenidas en el mes de septiembre y febrero se observó un incremento significativo en el diámetro del túbulo, grosor del epitelio germinal y número de células del epitelio germinal cuando fueron comparadas con las muestras de junio ( $\mathrm{p} \leq 0.05$ ). Solo en las muestras de febrero hubo presencia de espermátides. En conjunto, nuestros resultados sugieren la existencia de variaciones estacionales en la actividad reproductiva de $T$. brasiliensis, bajo las condiciones en que se realizó el estudio.

PALABRAS CLAVE: Tadarida brasiliensis; Morfometría; Testiculo; Cambios estacionales.

\section{REFERENCES}

Almeida, F. F.; Leal, M. C. \& França, L. R. Testis morphometry, duration of spermatogenesis, and spermatogenic efficiency in the wild boar (Sus scrofa scrofa). Biol. Reprod., 75(5):7929, 2006.

Ávila-Flores, R. \& Fenton, M. B. Use of spatial features by foraging insectivorous bats in a large urban landscape. $J$. Mammal., 86(6):1193-204, 2005.

Beguelini, M. R.; Moreira, P. R.; Faria, K. C.; Marchesin, S. R. \& Morielle-Versute, E. Morphological characterization of the testicular cells and seminiferous epithelium cycle in six species of Neotropical bats. J. Morphol., 270(8):943-53, 2009.

Bernanke, J. \& Köhler, H. R. The impact of environmental chemicals on wildlife vertebrates. Rev. Environ. Contam. Toxicol., 198:1-47, 2009.

Estrada, F. E.; Peralta, Z. L. \& Rivas, M. P. Manual de Técnicas Histológicas. Ciudad de México, AGT, 1982.

Fietz, J.; Pflug, M.; Schlund, W. \& Tataruch, F. Influences of the feeding ecology on body mass and possible implications for reproduction in the edible dormouse (Glis glis). J. Comp. Physiol. B, 175(1):45-55, 2005.

Gannon, W. L. \& Sikes, R. S. Guidelines of the American Society Mammalogists for the Use of Wild Mammals in Research. J. Mammal., 88(3):809-23, 2007.
Happold, D. C. \& Happold, M. Reproduction of Angola freetailed bats (Tadarida condylura) and little free-tailed bats (Tadarida pumila) in Malawi (Central Africa) and elsewhere in Africa. J. Reprod. Fertil., 85(1):133-49, 1989.

Hammer, Ø.; Harper, D. A. T. \& Ryan, P. D. PAST: Paleontological Statistics Software Package for Education and Data Analysis. Palaeontologia Electrónica, 2001. Available in: http://palaeo-electronica.org/2001_1/past/ issue1_01.htm.

Krutzsch, P. H.; Fleming, T. H. \& Crichton, G. Reproductive Biology of male Mexican free-tailed bats (Tadarida brasiliensis mexicana). J. Mammal., 83(2):489-500, 2002.

Medellin, R.; Arita, H. \& Sánchez, O. Identificación de los murciélagos de México. Clave de campo. Ciudad de México, Instituto de ecología UNAM, 2008.

Racey, P. A. \& Entwistle, A. C. Life-history and reproductive strategies of bats. In Crichton, E. G. \& Krutzsch, P. H. Reproductive biology of bats. San Diego, Academic Press, 2000. pp.363-414.

Romano, M. C.; Maidagan, J. I. \& Pire, E. F. Behavior and demography in an urban colony of Tadarida brasiliensis (Chiroptera: Molossidae) in Rosario, Argentina. Rev. Biol. Trop., 47(4):1121-7, 1999.

Russell, A. L.; Medellin, R. A. \& McCracken, G. F. Genetic 
PÉREZ-RIVERO, J.; RENDON-FRANCO, E.; PÉREZ-MARTíNEZ, M.; ÁVALOS-RODRIGUEZ, A. \& AVILA-FLORES, R. Morphometric differences in testicular tissue of Tadarida brasiliensis bats from the urban area of Mexico City during summer, autumn, and winter. Int. J. Morphol., 31(3):932-936, 2013.

variation and migration in the Mexican free-tailed bat (Tadarida brasiliensis mexicana). Mol. Ecol., 14(7):2207-22, 2005.

Schön, J.; Göritz, F.; Streich, J. \& Blottner, S. Histological organization of roe deer testis throughout the seasonal cycle: variable and constant components of tubular and interstitial compartment. Anat. Embryol. (Berl.), 208(2):151-9, 2004.

Stebbings, R. E. Conservation of European bats. London, Cristopher Helm, 1988.

Wilkins, T. K. Tadarida brasiliensis. Mamm. Spec., 331:1-10, 1989.

\section{Correspondence to:}

Dr. Juan J. Pérez-Rivero

Departamento de Producción Agrícola y Animal Universidad Autónoma Metropolitana Unidad Xochimilco Calzada del Hueso 1100 colonia Villa Quietud Delegación Coyoacán

Ciudad de México, CP 04960

MÉXICO

Email: jjperez1_1999@yahoo.com

Received: 29-11-2012

Accepted: 10-08-2013 